\title{
A COMPARATIVE STUDY OF THE SEED GERMINATION CAPABILITIES OF ANACAMPTIS PALUSTRIS (ORCHIDACEAE), A THREATENED TERRESTRIAL ORCHID, AND OTHER MORE COMMON ANACAMPTIS SPECIES, BY ASYMBIOTIC CULTURE IN VITRO
}

\author{
SARA MAGRINI ${ }^{1, *}$, ALESSANDRO DE CARLI ${ }^{1}$, \\ SILVANO ONOFRI ${ }^{2}$, and ANNA SCOPPOLA ${ }^{3}$

\footnotetext{
${ }^{1}$ Tuscia Germplasm Bank, Botanical Gardens, University of Tuscia, Largo dell'Università, I-01100 Viterbo, Italy

${ }^{2}$ Department of Ecological and Biological Sciences, University of Tuscia, largo dell'Università, I-01100 Viterbo, Italy

${ }^{3}$ Department DAFNE, University of Tuscia, largo dell'Università, I-01100 Viterbo, Italy

*Corresponding author: magrini@unitus.it; Tel.: +39 0761 357091; Fax: +39 0761357028
}

\begin{abstract}
The increasing emphasis on terrestrial orchid conservation has led to conservation actions for a wide range of threatened Mediterranean species. Many terrestrial orchids are currently at great risk for extinction as a result of a multiplicity of threatening processes. We focus on orchid seed germination capabilities in vitro, specifically germination capability of a threatened species, Anacamptis palustris, compared to three other more common species (A. laxiflora, A. morio, and A. papilionacea), and also discuss its potential impact on orchid distribution and conservation. Asymbiotic germination tests were performed with mature seeds using BM- 1 medium. In vitro seed germination and protocorm developmental stages were evaluated up to 20 weeks after sowing. Significant differences in seedling development were detected among the species, and a correlation was evident between the rarity of the species and their germinability. Thus, the presence of intrinsic, biological factors that affect and limit the distribution of $A$. palustris may exist.
\end{abstract}

Keywords: Anacamptis (Orchis) palustris, in vitro asymbiotic germination, conservation, germination indices, mature seeds, threatened species

\section{Introduction}

The increasing emphasis on terrestrial orchid conservation has lead to conservation actions for a wide range of threatened Mediterranean orchid species. Terrestrial orchids, which make up one-third of all orchid species, are at great risk for extinction, because of a multiplicity of threatening processes. They are particularly sensitive to habitat fragmentation or changes due to human disturbances and their effects, so much so that many environmental and anthropic factors determine their distribution, decline, and conservation status. In response to threats to orchid species, integrated multidisciplinary conservation approaches, including in vitro techniques, are suggested to improve the understanding and modification of processes contributing to orchid rarity, and to facilitate the conservation of some of the most threatened taxa. Several recent reports highlight the need to study both environmental and biological factors linked to habitat changes, such as highly specific mycorrhizal and pollinator relationships, to explain rarity, decline or risk in orchids (Swartz and Dixon 2009; Vereecken et al. 2010). Here, we focus on seed germination capability another important aspect of orchid biology - and discuss its impact on orchid distribution, abundance and conservation.

Anacamptis palustris (Jacq.) R. M. Bateman, Pridgeon and M. W. Chase (Orchidaceae), the marsh or bog orchid formerly known as Orchis palustris, is a Euro-Mediterranean species. It is widely distributed in the western
Mediterranean area, but also has been found (sparsely) in central and northern Europe, as far north as Gotland, and reaching Transcaucasia eastwards (Arduino et al. 1996; Bateman et al. 2003). This species grows exclusively in marsh habitats, typically in retrodunal areas along the coast, with the exception of Central Italy, where a few populations live in highly saline areas, such as sulphuric springs (Cozzolino et al. 2003a,b). Mediterranean coastal marsh habitats have been strongly affected by human activity, and suitable habitats are becoming increasingly reduced in size, fragmented or altered. Thus, the current distribution of $A$. palustris is highly patchy and a severe reduction in habitat extent has been observed, even if some local populations seem quite large. Moreover, this orchid species is genetically depauperate, especially in Italy where genetic variability is very low both within and among populations (Arduino et al. 1996). As a consequence, $A$. palustris is considered to be Endangered in Italy (Conti et al. 1997; Alessandrini and Medagli 2008), and threatened in Austria, Czech Republic, France, Germany, Sweden, Switzerland, and in many other European states (Schnittler et al. 2001).

Since 2006, the Tuscia Germplasm Bank (Botanical Gardens, University of Tuscia, Viterbo, Italy) has been monitoring and studying a small population of A. palustris that grows near the Bagnaccio thermal well (Viterbo, Northern Latium, Italy). In the spring of 2008, this population experienced a very strong demographic decline, due to anthropic actions that drastically reduced its habitat, resulting in a dramatic drop in the number of plants 
from about 300 to only 10 . Since June 2008, A. palustris seeds were collected for ex situ conservation of the germplasm of this threatened population (Magrini et al. 2011), and for in vitro reproduction, because no information exists on mature seed germination and in vitro seedling development for this species.

Asymbiotic seed germination of temperate terrestrial orchids is sometimes difficult, and survival rates of deflasked seedlings even more so (Arditti et al. 1982b; Rasmussen 1995; Miyoshi and Mii 1998). For many orchid species, the green capsule technique, or embryo culture, has a number of advantages: the immature seeds do not need to be sterilized, thereby avoiding possible damage, nor treated for dormancy release, and they yield higher germination rates than the mature seeds (Linden 1980; Arditti et al. 1982a,b; Ballard 1987; Mitchell 1989; De Pauw and Remphrey 1993; Rasmussen 1995; Light and MacConaill 1998; Yamazaki and Miyoshi 2006; Sgarbi et al. 2007). The disadvantages of immature seed techniques are the difficulty to harvest the capsules at the right developmental stage, which requires continuous monitoring of the plant phenology, because the maturation may be faster or slower depending on the species, habitat, climate variability, and other environmental factors, and the need for culture immediately after harvest (Steele 1996; Kitsaki et al. 2004; Hicks 2006). In light of these disadvantages, the use of mature seeds is still generally preferred. In fact, even though they require surface sterilization and seed dormancy must be broken, this method enables collection of a homogeneous sample of mature seeds that remain viable for long periods under refrigeration (Steele 1996; Kitsaki et al. 2004; Seaton and Pritchard 2008; Seaton et al. 2010).

Sodium hypochlorite, which is commonly used for the sterilization of orchid seeds, has also been reported to be effective for breaking seed dormancy and to have a stimulatory effect on seed germination in some orchid species (Miyoshi and Mii 1988; Rasmussen 1995). Surface treatment with sodium hypochlorite until the seeds lose their dark colour, has both sterilizing and scarifying effects: it increases the permeability of the testa and the subsequent germination percentage, allowing access of water to the embryo, a very slow process without mycorrhizal symbiosis, if possible at all (Harvais and Hadley 1967; Lindén 1980). The addition of a detergent such as Tween 80 (a sorbitolanydride) is necessary for effective chemical treatment of the testa in aqueous solutions, because the detergent contains both hydrophilic and lipophilic groups, thus improving contact between water and lipoid surfaces such as the seed coat (Rasmussen 1995).

Most orchid media contain similar components, such as sugars, mineral salts, and agar. However, asymbiotic germination of orchid seeds seems to be influenced principally by the nitrogen source and nitrogen availability (Mead and Bulard 1975, 1979; Van Waes and Debergh 1986; van Waes 1987; Malmgren 1992, 1996; Kauth et al. 2006; Stewart and Kane 2006). This may be because of enzyme synthesis or activation within the developing protocorms. Thus, ensuring that organic nitrogen can be more readily utilized by young protocorms as available amino acids may bypass certain steps of the nitrogen assimilation process, such as the production of nitrate reductase, which requires several months following seed imbibition (Raghavan and Torrey 1964; Malmgren 1992, 1996).

The aims of this study are 1) to reproduce in vitro Anacamptis palustris and 2) to assess whether variations in germination capability directly correlate with the distribution, abundance, and frequencies of terrestrial orchid species. Comparisons were made between the germination capability of a rare species of terrestrial orchid, A. palustris, and three other more common species: the loose flowered orchid, A. laxiflora (Lam.) R. M. Bateman, Pridgeon and M. W. Chase, a species quite common in Italy that grows in the same habitat of A. palustris but with larger populations; the green-winged orchid, $A$. morio (L.) R. M. Bateman, Pridgeon and M. W. Chase, and the butterfly orchid, A. papilionacea (L.) R. M. Bateman, Pridgeon and M. W. Chase, both chosen for their wide distribution in Italy.

\section{Materials and methods}

\section{Collection of seeds}

Seeds from 7 wild orchid populations of Anacamptis palustris (Jacquin) R. M. Bateman, Pridgeon and M. W. Chase (Orchidaceae), A. laxiflora (Lam.) R. M. Bateman, Pridgeon and M. W. Chase, A. morio (L.) R. M. Bateman, Pridgeon and M. W. Chase, and A. papilionacea (L.) R. M. Bateman, Pridgeon and M. W. Chase, growing in Northern Latium (Italy) were utilized in this study (see Table 1). A total of 10-20 plants from each population were marked during anthesis to make them recognizable during the fruiting phase. Mature capsules were collected after ca. 1 month. A total of 186 capsules were harvested from June to July 2010 from 52 stems, with an average of 3.4 capsules/plant. The capsules were placed in paper envelopes, and taken to the Tuscia Germplasm Bank (Botanical Gardens, University of Tuscia, Viterbo, Italy), where identification codes were assigned to each. There, mature seeds were extracted from opened capsules using sieves with a mesh size of $100 \mu \mathrm{m}$, put in $4 \mathrm{ml}$ glass vials, and stored at $\mathrm{T}=5 \pm 1{ }^{\circ} \mathrm{C}$ until use.

\section{Germination tests}

Germination tests were started in July 2010. Seeds were surface sterilized in a $5 \% \mathrm{NaOCl}$ solution (Hicks 2006; Sgarbi et al. 2007) supplemented with a drop of Tween 80 (to improve the efficiency of sterilization and scarification), for a few minutes, until bleaching of the seeds was observed. Seeds were then rinsed three times 
Table 1 List of the species studied, with an indication of their rarity in Italy (1: very common; 2: common; 3: very rare) according to Rossi (2002) and GIROS (2009), collection location, and information about the marking and the collection phases; in the last column the Tuscia Germplasm Bank (BGT) accession codes are reported.

\begin{tabular}{|c|c|c|c|c|c|c|c|c|}
\hline \multirow[b]{2}{*}{ Species } & \multirow{2}{*}{$\begin{array}{l}\text { Rarity } \\
\text { index }\end{array}$} & \multirow{2}{*}{$\begin{array}{l}\text { Collection location } \\
\text { (Viterbo, Northern Latium, Italy) }\end{array}$} & \multicolumn{2}{|c|}{$\begin{array}{c}\text { Marking } \\
\text { of flowering plant }\end{array}$} & \multicolumn{3}{|c|}{$\begin{array}{c}\text { Collection } \\
\text { of mature capsules }\end{array}$} & \multirow{2}{*}{$\begin{array}{l}\text { BGT } \\
\text { code }\end{array}$} \\
\hline & & & $\begin{array}{l}\text { Date } \\
(2010)\end{array}$ & $\begin{array}{l}\text { No of } \\
\text { plants }\end{array}$ & $\begin{array}{l}\text { Date } \\
(2010)\end{array}$ & $\begin{array}{l}\text { No of } \\
\text { plants }\end{array}$ & $\begin{array}{c}\text { No } \\
\text { pods } \\
\text { /plant }\end{array}$ & \\
\hline \multirow{2}{*}{ Anacamptis laxiflora } & \multirow{2}{*}{2} & Vetralla, loc. Monte Calvo & May 2 & 10 & July 4 & 4 & 2.5 & A11710 \\
\hline & & Viterbo, loc. Bagnaccio & May 10 & 20 & June 15 & 10 & 3.8 & A13010 \\
\hline \multirow{2}{*}{ Anacamptis morio } & \multirow{2}{*}{1} & Ischia di Castro, loc. Vallerosa & May 18 & 10 & June 15 & 8 & 7.6 & A10210 \\
\hline & & Viterbo, loc. Bagnaccio & May 3 & 12 & June 15 & 9 & 3.1 & A10310 \\
\hline Anacamptis palustris & 3 & Viterbo, loc. Bagnaccio & June 15 & 4 & July 14 & 4 & 3.0 & A13210 \\
\hline \multirow{2}{*}{ Anacamptis papilionacea } & \multirow{2}{*}{1} & Monte Casoli Nature Reserve, Bomarzo & May 5 & 17 & June 10 & 4 & 4.0 & A9710 \\
\hline & & Arlena di Castro & April14 & 15 & June 15 & 13 & 2.5 & A10510 \\
\hline
\end{tabular}

Table 2 Germination test data: list of the species with BGT and test codes, number of sowed seeds for each test, number and percentages of empty seeds.

\begin{tabular}{|c|c|c|c|c|c|}
\hline Species & BGT code & Test code & No sowed seeds & No empty seeds & $\%$ empty seeds \\
\hline \multirow{2}{*}{ Anacamptis laxiflora } & A 11710 & A LAX 1 & 273 & 64 & $23 \%$ \\
\hline & A 13010 & A LAX 2 & 866 & 276 & $32 \%$ \\
\hline \multirow{2}{*}{ Anacamptis morio } & A 10310 & A MOR 1 & 403 & 176 & $44 \%$ \\
\hline & A 10210 & A MOR 2 & 300 & 29 & $10 \%$ \\
\hline Anacamptis palustris & A 13210 & A PAL & 237 & 71 & $30 \%$ \\
\hline \multirow{2}{*}{ Anacamptis papilionacea } & A 10510 & A PAP 1 & 385 & 91 & $24 \%$ \\
\hline & A 9710 & A PAP 3 & 297 & 52 & $18 \%$ \\
\hline
\end{tabular}

with sterile distilled water followed by centrifugation at $6000 \mathrm{rpm}$ for $3 \mathrm{~min}$. between rinses.

BM-1 Terrestrial Orchid Medium (PhytoTechnology Laboratories ${ }^{\oplus}$ Shawnee Mission, KS, USA) was used as a culture medium: it is a Basic Medium modified according to Van Waes and Debergh (1986) that contains only organic nitrogen, $0.5 \mathrm{~g} / \mathrm{l}$ casein enzymatic hydrolysate and $0.1 \mathrm{~g} / \mathrm{l} \mathrm{L}$-glutamine. The $\mathrm{pH}$ of the medium was adjusted to $6.3 \pm 0.1$ before autoclaving at $121^{\circ} \mathrm{C}$ and $101 \mathrm{kPa}$ for $20 \mathrm{~min}$. The medium was supplemented with $0.6 \%$ agar (Plant Tissue Culture Grade, AppliChem, Darmstadt, Germany) (Sgarbi et al. 2007) and 0.1\% activated charcoal (Plant Tissue Culture Tested, PhytoTechnology Laboratories $^{\oplus}$ Shawnee Mission, Kansas, USA) (van Waes 1987). Approximately 100-300 seeds (Table 2) were sown under axenic conditions in each Petri dish (6 cm in diam.), containing $15 \mathrm{ml}$ of BM-1 medium. Three replicate dishes were prepared for each accession of seeds. Germination dishes were sealed with Parafilm ${ }^{\circ}$ (Pechiney Plastic Packaging, Chicago, IL, USA), wrapped in aluminium foil to exclude light, and incubated at $\mathrm{T}=24 \pm 1{ }^{\circ} \mathrm{C}$ in darkness (Scrugli and Cogoni 1994; Lauzer et al. 2007).

The number of empty seeds was counted in each dish (Table 2). This number was subtracted from the total number of seeds/dish to calculate the germination indices. Each dish was then examined biweekly for a period of 20 weeks, and all seeds and seedlings were counted using a $1 \times 1 \mathrm{~cm}$ grid under a stereoscopic microscope
(Nikon SMZ 1000). The process of seed germination was recorded according to embryonic developmental stage, modified from Miyoshi and Mii (1995) and Yamazaki and Miyoshi (2006): Stage 0, 'No germination' stage. No growth of the embryo occurs; Stage 1, 'Pre-germination' stage. The embryo swells to fill the seed coat; Stage 2, 'Germination' stage. The embryo emerges from the seed coat; Stage 3, 'Protocorm' stage. The embryo is completely discharged from the seed coat; Stage 4, 'Rhizoid' stage. Rhizoids are formed on the protocorm surface; Stage 5, 'Shoot' stage. The shoot is differentiated from the protocorm.

Seedlings with ca. $0.5-0.8 \mathrm{~cm}$ long leaves were transferred under axenic conditions to flasks containing fresh medium for continued growth, and incubated at $\mathrm{T}=24 \pm 1{ }^{\circ} \mathrm{C}$, with a $16 / 8 \mathrm{~h}$ photoperiod, under coolwhite fluorescent illumination (Osram Dulux L 36W/840 Lumilux, $2900 \mathrm{~lm}$ ).

\section{Germination indices}

The germination capability of tested seeds from the different species was calculated and analyzed using 9 germination indices: germinability or final germination percentage $(G)$, recorded as the total percentage of Stages 2-5 after 20 weeks; elapsed time until the first germinant is observed $\left(\mathrm{T}_{1}\right)$, recorded as the number of days required to reach Stage 2; time required to reach $50 \%$ germination 
$\left(T_{50}\right)$, where $T_{50}=t_{i}+\left[\left(N / 2-n_{i}\right)\left(t_{j}-t_{i}\right)\right] /\left(n_{j}-n_{i}\right), N$ is the final number of germination, and $n_{i}, n_{j}$ are the cumulative number of seeds germinated from adjacent counts when $n_{\mathrm{i}}<\mathrm{N} / 2<\mathrm{n}_{\mathrm{j}}$ ); time to reach maximum germination $\left(\mathrm{T}_{\max }\right)$; mean germination time (MT); coefficient of variation of the germination time $\left(\mathrm{CV}_{\mathrm{t}}\right)$; mean germina- tion rate or germinants per day (MR); uncertainty of the germination process $(\mathrm{U})$, a measure of the uncertainty associated with the distribution of the relative frequency of germination, $0 \leq \mathrm{U} \leq \log _{2} \mathrm{~N}$, where $\mathrm{N}$ is the total number of germinated seeds; synchrony of the germination process $(Z)$, an index of the degree of germination over-
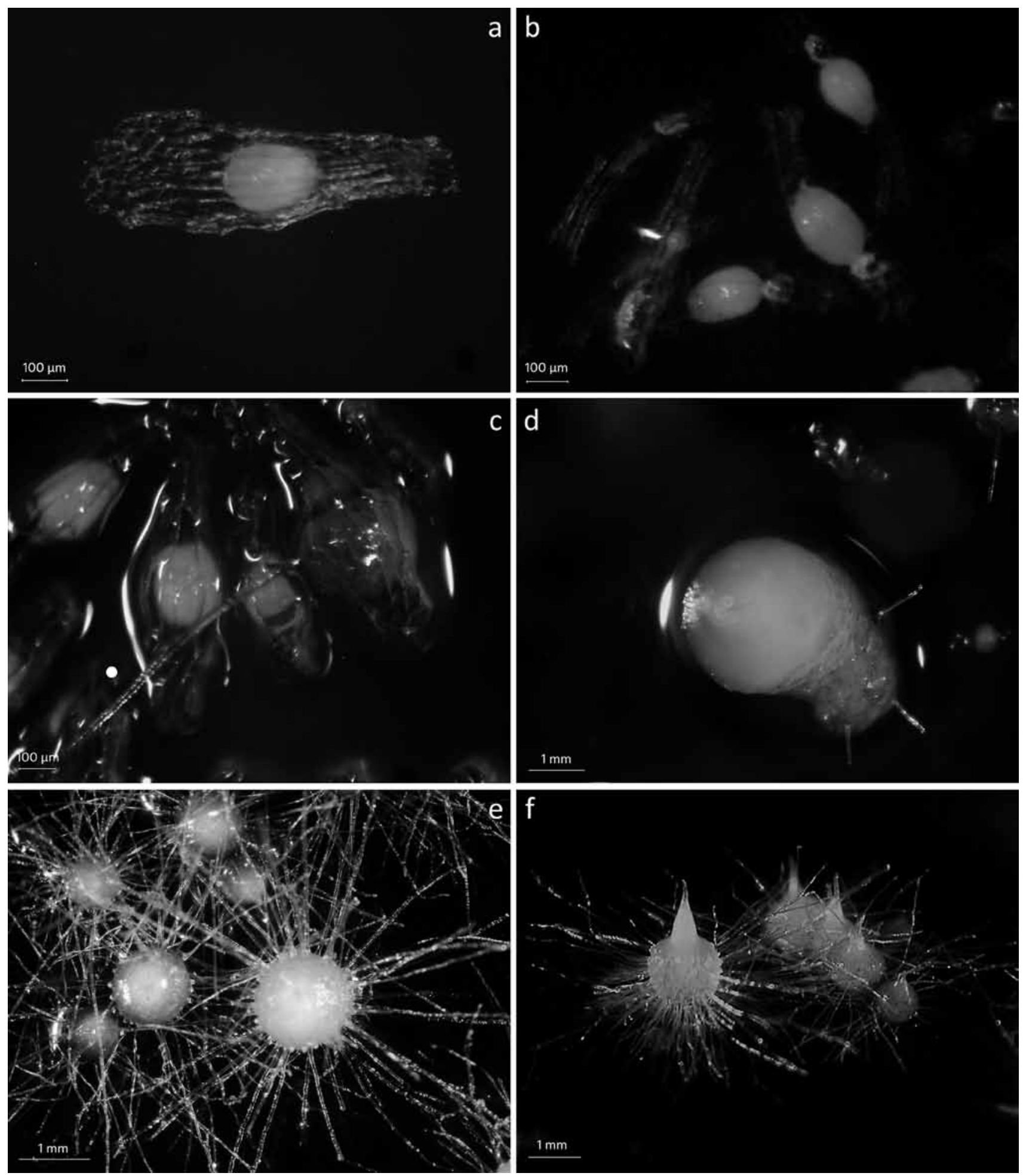

Fig. 1 Successive developmental stages of mature seeds of Anacamptis palustris, from germination to seedling formation, by asymbiotic culture in vitro. (a) Stage 0: 'No germination stage', no growth of embryo occurs. (b) Stage 1: 'Pre-germination stage', embryo swells in the width of the seed coat. (c) Stage 2:'Germination stage', embryo emerges from the seed coat. (d) Stage 3:'Protocorm stage', embryo completely emerges from the seed coat. (e) Stage 4: 'Rhizoid stage', rhizoids are formed on the surface of the protocorm. (f) Stage 5: 'Shoot' stage. The shoot is differentiated from the protocorm. 
lapping $(0 \leq \mathrm{Z} \leq 1)$. The last 5 indices were calculated as described by Ranal et al. (2006).

Germination data were analyzed by one-way ANOVA using GraphPad Prism 5.0, followed by Tukey's Multiple Comparison Test to test for significant differences among orchid species. Pearson's Correlation Test was performed to test for correlation between the rarity index and all other germination indices at $95 \%$ confidence interval $(95 \% \mathrm{CI})$.

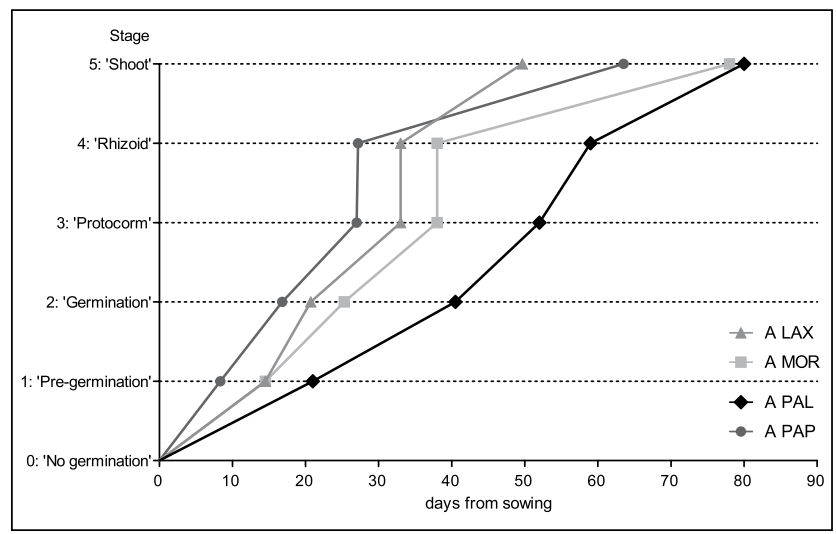

Fig. 2 Comparison of in vitro asymbiotic germination trends in Anacamptis species. The graph shows the average elapsed time before first observation of each developmental stage for the 4 species: A LAX: A. laxiflora; A MOR: A. morio; A PAL: A. palustris; A PAP: A. papilionacea.

\section{Results}

Mature seeds of Anacamptis palustris germinated and grew to all five developmental stages on the asymbiotic medium (Fig. 1), but two months were required before Stage 4 seedlings were observed. In contrast, seeds from the other three more common Anacamptis species attained Stages 3-4 after only one month in vitro (Figs. 2-3), and shoots (Stage 5) were visible after two months. Anacamptis papilionacea displayed higher total germination values for all observation periods (Fig. 3). Total germination percentages for $A$. papilionacea were: $48.2 \pm 16.0 \%, 75.5 \pm 13.7 \%, 83.2 \pm 6.1 \%$, and $84.3 \pm 4.9 \%$, at 1,2,3, and 4 months, respectively. Anacamptis laxiflora, on the other hand, was found to display higher percentages of protocorms with shoots (Stage 5), even after only 1 month (Stage 5 percentages were $0.3 \pm 0.5 \%, 13.2 \pm 0.3 \%$, $35.9 \pm 17.1 \%$, and $53.6 \pm 26.1 \%$ after $1,2,3$, and 4 months, respectively). In contrast to these species, $A$. palustris was observed to display the lowest total germination percentages $(13.1 \pm 7.9 \%, 29.1 \pm 6.1 \%, 31.8 \pm 7.3 \%$, and $52.0 \pm$ $12.7 \%$ after $1,2,3$, and 4 months, respectively). In fact, the germination trend for A. palustris (Fig. 2 and 3 ) is significantly different from $A$. papilionacea (Tukey's Test; $P<0.01$ ) and A. morio (Tukey's Test; $P<0.05$ ).

After 4 months, the seedlings with the longest (ca. $0.5-0.8 \mathrm{~cm}$ ) hyaline leaves were transferred to flasks containing fresh BM-1 medium (160 of A. laxiflora and 60

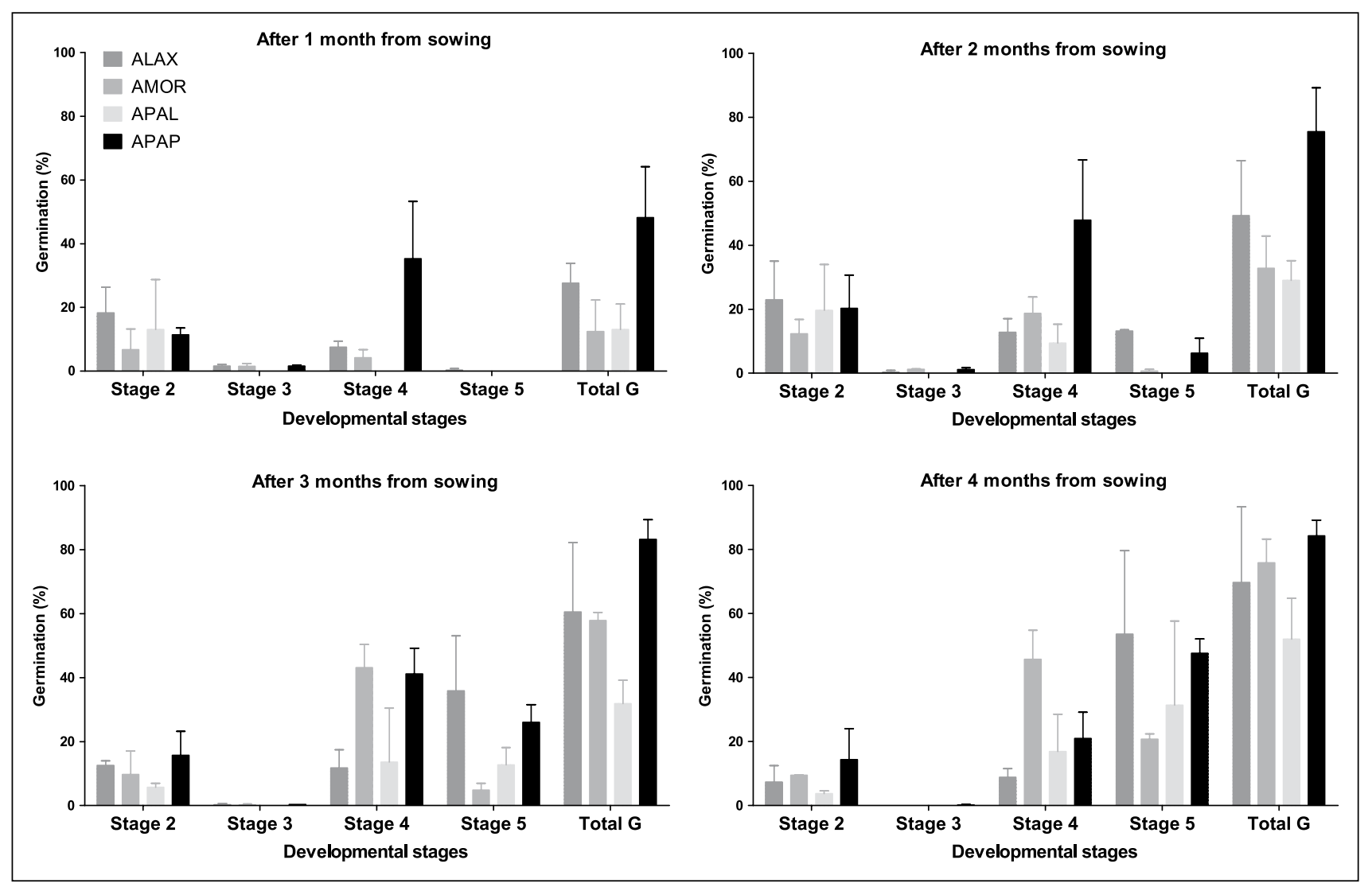

Fig. 3 Germination percentages (mean \pm SD) of the 4 Anacamptis species for each developmental stages, recorded 1, 2, 3, and 4 months after sowing (A LAX: A. laxiflora; A MOR: A. morio; A PAL: A. palustris; A PAP: A. papilionacea). 


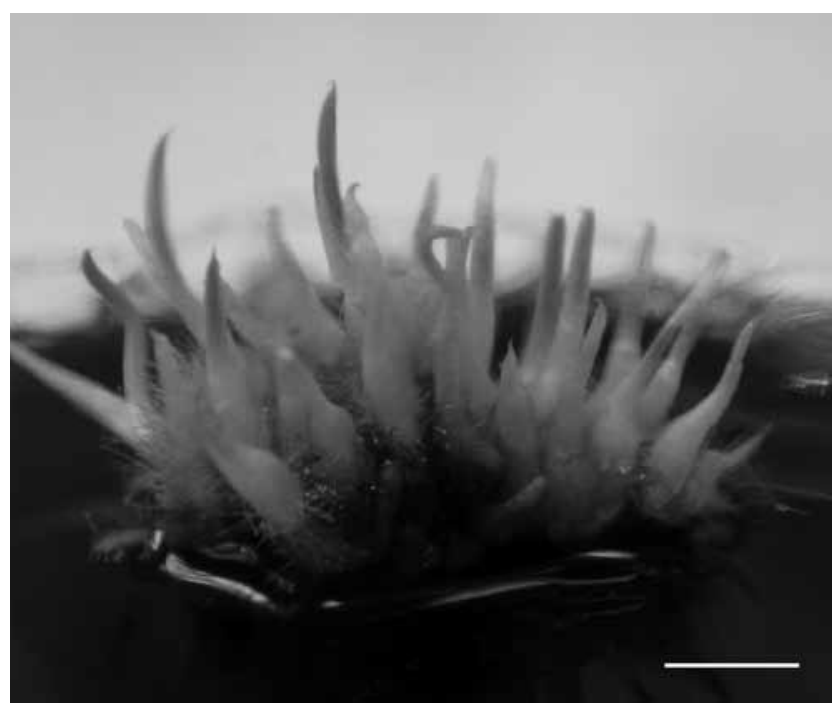

Fig. 4 Anacamptis papilionacea seedlings with green leaves and roots, transferred to flasks containing fresh BM-1 medium (scale $\operatorname{bar}=1 \mathrm{~cm})$.

of A. papilionacea). After 1 week of culture, the leaf color became green, and all of the seedlings showed continued growth and leaf elongation (Fig. 4).

Most of germination indices (Table 3 ) were statistically significantly different between these orchid species $\left(\mathrm{T}_{1}\right.$ : $F_{3,20}=28.03, P<0.0001 ; \mathrm{T}_{50}: F_{3,20}=20.28, P<0.0001$; $\mathrm{T}_{\max }: F_{3,20}=3.97, P<0.05 ;$ MT: $F_{3,20}=33.90, P<0.0001$; $\mathrm{CV}_{\mathrm{t}}: F_{3,20}=3.72, P<0.05 ;$ MR: $\left.F_{3,20}=39.10, P<0.0001\right)$. First seed germination $\left(\mathrm{T}_{1}\right)$ was scored for Anacamptis papilionacea (16.8 days after sowing) (Fig. 2, Table 3 ), that displayed also the shortest time to $50 \%$ germination $\left(\mathrm{T}_{50}\right)$ and the shortest maximum germination $\left(\mathrm{T}_{\max }\right)$. In contrast, $A$. palustris displayed the longest $\mathrm{T}_{1}$ and $\mathrm{T}_{\max }$ times, with extremely significant differences for $\mathrm{T}_{1}$ (40.5 days,
Tukey's Test; $P<0.001)$ and significant differences for $\mathrm{T}_{\max }$ (134.0 days, Tukey's Test; $\left.P<0.05\right)$. The maximum $\mathrm{T}_{50}$ was observed for A. morio (69.5 days), which was significantly different from $A$. papilionacea and A. laxiflora (Tukey's Test; $P<0.001$ ), as well as from $A$. palustris (Tukey's Test; $P<0.01$ ).

At $\mathrm{T}_{\text {max }}$, maximum germinability (G) was recorded for both A. papilionacea (84.6\%, in the shortest time, 113.8 days), and A. morio (75.9\%). These germinability values are significantly greater (Tukey's Test; $P<0.05$ ) than the values recorded for $A$. palustris seeds, which show the minimum germinability $(55.7 \%)$ with the longest germination time (134.0 days).

The lowest mean germination time (MT) was recorded for A. papilionacea (47.4 days; Tukey's Test; $P<0.001$ ). In contrast, longer mean germination times were recorded for A. morio (81.6 days) and A. palustris (79.4 days), which in addition showed the lowest coefficient of variation of germination time $\left(\mathrm{CV}_{t}\right)$, and the same mean germination rates (MR, 0.01 germinants/day).

The low $\mathrm{Z}$ values recorded for all of the species (0.2-0.3, much less than 1) indicate a very low degree of synchrony between the seeds during germination. This lack of synchrony was further confirmed by the low $U$ values observed, which suggest a low degree of germination spreading over time.

The results of the Pearson's Correlation Test (95\% confidence interval, significant correlation for $\alpha=0.05$ ) performed between the rarity index of the species ( $\mathrm{Ta}$ ble 1) and the germination indices (Table 3 ) highlight a significant correlation between the rarity of the species and their germinability $(\mathrm{G})$ (Pearson's $R$ : -0.9537 ; p-value (two-tailed): $0.0231^{*} ; R^{2}=0.9096$ ). No statistically significant correlation was observed with the other germination indices.

Table 3 Germination indices (mean \pm SD) of seeds from the 4 Anacamptis species studied.

\begin{tabular}{|l|c|c|c|c|c|c|c|c|c|}
\hline Species & $\mathbf{G}(\%)$ & $\mathbf{T}_{\mathbf{1}}$ (days) & $\mathbf{T}_{\mathbf{5 0}}$ (days) & $\mathbf{T}_{\max }$ (days) & $\mathbf{M T}$ (days) & $\mathbf{C V}_{\mathbf{t}}(\%)$ & $\begin{array}{c}\mathbf{M R} \text { (germi- } \\
\text { nants/day) }\end{array}$ & $\mathbf{U}$ (bit) & $\mathbf{Z}$ \\
\hline A LAX & $69.7 \pm 3.9 \mathrm{a}, \mathrm{b}$ & $20.7 \pm 3.6 \mathrm{a}, \mathrm{b}$ & $46.9 \pm 2.9 \mathrm{a}, \mathrm{b}$ & $129.3 \pm 7.2 \mathrm{a}, \mathrm{b}$ & $62.9 \pm 1.0 \mathrm{a}$ & $49.0 \pm 2.8 \mathrm{a}$ & $0.02 \pm 0.00 \mathrm{a}$ & $2.5 \pm 0.4 \mathrm{a}$ & $0.2 \pm 0.0 \mathrm{a}$ \\
\hline A MOR & $75.9 \pm 6.4 \mathrm{a}$ & $25.3 \pm 8.8 \mathrm{a}$ & $69.5 \pm 13.1 \mathrm{c}$ & $134.0 \pm 7.7 \mathrm{a}$ & $81.6 \pm 1.6 \mathrm{~b}$ & $37.4 \pm 6.4 \mathrm{~b}$ & $0.01 \pm 0.00 \mathrm{~b}$ & $1.9 \pm 0.4 \mathrm{a}$ & $0.2 \pm 0.1 \mathrm{a}$ \\
\hline A PAL & $55.7 \pm 15.6 \mathrm{~b}$ & $40.5 \pm 0.7 \mathrm{c}$ & $51.0 \pm 0.2 \mathrm{~b}$ & $134.0 \pm 0.1 \mathrm{a}$ & $79.4 \pm 0.5 \mathrm{~b}$ & $47.6 \pm 0.5 \mathrm{a}, \mathrm{b}$ & $0.01 \pm 0.00 \mathrm{~b}$ & $1.9 \pm 0.5 \mathrm{a}$ & $0.2 \pm 0.0 \mathrm{a}$ \\
\hline A PAP & $84.6 \pm 4.3 \mathrm{a}$ & $16.8 \pm 1.2 \mathrm{~b}$ & $38.1 \pm 5.1 \mathrm{a}$ & $113.8 \pm 20.9 \mathrm{~b}$ & $47.4 \pm 0.8 \mathrm{c}$ & $40.5 \pm 2.0 \mathrm{a}, \mathrm{b}$ & $0.02 \pm 0.00 \mathrm{c}$ & $1.9 \pm 0.1 \mathrm{a}$ & $0.3 \pm 0.1 \mathrm{a}$ \\
\hline P value & $<0.05$ & $<0.0001$ & $<0.0001$ & $<0.05$ & $<0.0001$ & $<0.05$ & $<0.0001$ & $\mathrm{~ns}(0.1259)$ & $\mathrm{ns}(0.0908)$ \\
\hline F $_{3,20}$ & 5.770217 & $\mathbf{2 8 . 0 3 0 8 5}$ & $\mathbf{2 0 . 2 7 9 4 5}$ & 3.969223 & $\mathbf{3 3 . 9 0 1 7 8}$ & 3.722474 & $\mathbf{3 9 . 1 0 4 5 8}$ & 2.149257 & 2.478038 \\
\hline $\mathrm{R}^{2}$ & 0.4639600 & $\mathbf{0 . 8 0 7 8 6 3 3}$ & $\mathbf{0 . 7 5 2 5 9 2 7}$ & 0.3731914 & $\mathbf{0 . 8 3 5 6 6 8 7}$ & 0.3583044 & $\mathbf{0 . 8 5 4 3 4 8 1}$ & 0.2437926 & 0.2709807 \\
\hline B (P) & 5.641232 & $\mathbf{3 0 . 1 0 3 1 5}$ & $\mathbf{3 7 . 4 2 4 1 9}$ & $\mathbf{3 4 . 0 2 4 6 1}$ & $\mathbf{2 9 . 1 9 6 8 1}$ & $\mathbf{2 5 . 7 8 4 8 6}$ & $\mathbf{3 1 . 3 1 5 4 4}$ & 3.420312 & $\begin{array}{c}14.28993 \\
(\mathbf{P} 20.3312)\end{array}$ \\
$(0.1304)$ & $(\mathrm{P}<0.0001)$ & $(\mathrm{P}<0.0001)$ & $(\mathrm{P}<0.0001)$ & $(\mathrm{P}<0.0001)$ & $(\mathrm{P}<0.0001)$ & $(\mathrm{P}<0.0001)$ & $(0.05)$ \\
\hline
\end{tabular}

A LAX: A. laxiflora; A MOR: A. morio; A PAL: A. palustris; A PAP: A. papilionacea; G: percentage of germinating seeds; $T_{1}$ : First germination time; $T_{50}$ : Time to reach $50 \%$ germination; $T_{\max }$ : Time to reach maximum germination; $M T$ : mean germination time; $C V t$ : coefficient of variation of the germination time; $M R$ : mean germination rate; $U$ : uncertainty of the germination process; $Z$ : synchrony of germination process. For each parameter, the values followed by the same letters are not significantly different at the $5 \%$ level of probability, as determined by Tukey's test. ( $P$ : probability; $F$ : F-test distribution value, boldfaced values indicate statistically significant difference among matrixes (ANOVA; $P<0.0001$ ); $R^{2}$ : is the fraction of the overall variance attributable to differences among the group means, boldfaced values indicate great variance among the species; $B$ : Bartlett's test for equal variances; boldfaced values indicate significant difference among the variances (ANOVA; $P<0.0001)$. 


\section{Discussion}

This is the first report of successful asymbiotic germination of mature seeds of Anacamptis palustris, a threatened species of the European flora. In vitro techniques have found increasing use in the conservation of threatened orchids (Fay 1992; Vaasa and Rosenberg 2004; Znaniecka and Lojkowska 2004; Viswambharan et al. 2006). In fact, there are many recent reports of the successful in vitro asymbiotic reproduction of terrestrial orchids, which also used mature seeds from the Anacamptis species. Anacamptis laxiflora (Mead and Bulard 1975, 1979; Scrugli and Cogoni 1994), A. morio (van Waes and Debergh 1986; McKendrick 1996; Znaniecka and Lojkowska 2004), and A. papilionacea (Pedroso and Pais 1992) were cultured on different media. However, none of these previous reports include precise data on the germination or subsequent growth of protocorms, or the application of germination indices to analyze and compare the germination process of the species.

The choice of BM-1 as culture medium (van Waes and Debergh 1986) yielded good results, supporting rapid asymbiotic germination and advanced protocorm development in Anacamptis species. In all of the cultures, we could observe all germination stages, including the development of seedling with shoots, albeit with significant differences in times and percentages between the species. All of the orchids showed first germination within 16-40 days of sowing, and after 38-80 days they all had developed protocorms with rhizoids and shoots, for total germination percentages of $56 \%$ and $85 \%$. The asymbiotic germination of mature A. palustris seeds is an important result, even if this species displayed the longest germination times and lowest germination percentages, especially when compared to results from previous studies (Magrini et al. 2011) that provide no germination data for mature seed cultures on MS medium (Murashige and Skoog 1962) after 10 months, dramatically longer first germination times ( 6 months), and lower total germination percentages ( $6 \%$ after 6 months, and $35 \%$ after 10 months), using immature seeds.

Germination test results show significant differences between the germination trend found in the four Anacamptis species and most germination indices, especially germinability and first germination times, supporting the hypothesis that the presence of intrinsic, biological factors affect and limit the distribution of $A$. palustris. This correlation was confirmed by Pearson's Correlation Test results, which highlight a very significant correlation between the rarity of the analysed species and germinability. Short germination times and high germination percentages provide these orchids with many advantages to improve their dispersal efficiency and colonization ability, which in turn make them more adaptable to changing environmental conditions.

\section{Implications for conservation}

We highlight the need to consider the physical and biological factors which determine orchid rarity and conservation, as well as human disturbances and their effects. As highlighted by other authors (Swartz and Dixon 2009; Vereecken et al. 2010), extrinsic rarity in orchids is a reflection of both anthropogenic processes directly limiting or reducing the distribution and abundance of a species, and their biological ability to adapt themselves to environmental changes. In this study, we pointed out that germination capability can be one of the many causes of terrestrial orchid rarity. Although A. palustris and A. laxiflora grow in the same habitat, often together, they show different behaviours during the germination process that reflect the differences in their distribution and abundance.

Furthermore, we emphasize the importance of in vitro conservation efforts for threatened orchids. In fact, although the use of in vitro techniques in germplasm conservation is increasing, there is still great potential for further development of these methods, which could allow investigators to obtain plant material for DNA analyses, for the definition of reproduction protocols, and for autoecological or biological studies.

Future research should focus on improving the efficiency of $A$. palustris seed germination, especially testing the use of mycorrhizal fungi, on the acclimatization, and on the establishment of in situ methodologies, to further progress in the development of conservation techniques for rare and threatened orchids.

\section{Acknowledgements}

The authors thank S. Buono (GIROS - Italian Group for Research on Wild Orchids), for the harvesting of mature seeds of Anacamptis laxiflora.

\section{REFERENCES}

Alessandrini A, Medagli P (2008) Orchis palustris Jacq. In: Rossi G, Gentili R, Abeli T, Gargano D, Foggi B, Raimondo FM, Blasi C (eds) Flora da conservare. Iniziativa per l'implementazione in Italia delle categorie e dei criteri IUCN (2001) per la redazione di nuove Liste Rosse. Inform Bot Ital 40 suppl. 1: 93-95.

Arditti J, Clements MA, Fast G, Hadley G, Nishimura G, Ernst R (1982b) Orchid seed germination and seedling culture. A manual. In: Arditti J (ed) Orchid biology. Reviews and perspectives, II. Cornell University Press, Ithaca, NY, USA, pp 243-370.

Arditti J, Michaud JD, Oliva AP (1982a) Practical germination of North American and related orchids: Epipactis atrorubens, E. gigantea and E. helleborine. Am Orchid Soc Bull 51: $162-171$.

Arduino P, Verra F, Cianchi R, Rossi W, Corrias B, Bullini L (1996) Genetic variation and natural hybridization between Orchis laxiflora and Orchis palustris (Orchidaceae). Plant Syst Evol 202: 87-109. 
Ballard WW (1987) Sterile propagation of Cypripedium reginae from seeds. Am Orchid Soc Bull 56: 935-946.

Bateman RM, Hollingsworth PM, Preston J, Yi-Bo L, Pridgeon AM (2003) Molecular phylogenetics and evolution of Orchidinae and selected Habenariinae (Orchidaceae). Bot J Linn Soc 142: $1-40$.

Conti F, Manzi A, Pedrotti F (1997) Liste Rosse Regionali delle Piante d'Italia. WWF Italia, Società Botanica Italiana, Università di Camerino, Camerino, Italy.

Cozzolino S, Cafasso D, Pellegrino G, Musacchio A, Widmer A (2003a) Fine-scale phylogeographical analysis of Mediterranean Anacamptis palustris (Orchidaceae) populations based on chloroplast minisatellite and microsatellite variation. Mol Ecol 12: 2783-2792.

Cozzolino S, Noce ME, Musacchio A, Widmer A (2003b) Variation at a chloroplast minisatellite locus reveals the signature of habitat fragmentation and genetic bottlenecks in the rare orchid Anacamptis palustris (Orchidaceae). Am J Bot 90: 1681-1687.

De Pauw MA, Remphrey WR (1993) In vitro germination of three Cypripedium species in relation to time of seed collection, media, and cold treatment. Can J Bot 71: 879-885.

Fay MF (1992) Conservation of rare and endangered plants using in vitro methods. In Vitro Cell Dev Biol 28: 1-4.

GIROS (2009) Orchidee d'Italia: guida alle orchidee spontanee. Il Castello, Milano, Italy.

Harvais G, Hadley G (1967) The development of Orchis purpurella in asymbiotic and inoculated cultures. New Phytol 66: 217-230.

Hicks AJ (2006) Asymbiotic technique of orchid seed germination. The Orchid Seedbank Project, Chandler, Arizona, USA.

Kauth P, Vendrame W, Kane ME (2006) In vitro seed culture and seedling development of Calopogon tuberosus. Plant Cell Tissue Organ Cult 85(1): 91-102.

Kitsaki CK, Zygouraki S, Ziobora M, Kintzios S (2004) In vitro germination, protocorm formation and plantlet development of mature versus immature seeds from several Ophrys species (Orchidaceae). Plant Cell Rep 23: 284-290.

Lauzer D, Renaut S, St-Arnaud M, Barabé D (2007) In vitro asymbiotic germination, protocorm development, and plantlet acclimatization of Aplectrum hyemale (Muhl. ex Willd) Torr. (Orchidaceae). J Torrey Bot Soc 134: 344-348.

Light MHS, MacConaill M (1998) Factors affecting germinable seed yield in Cypripedium calceolus var. pubescens (Wild.) Correll and Epipactis helleborine (L.) Crantz (Orchidaceae). Bot J Linn Soc 126: 3-26.

Linden B (1980) Aseptic germination of seeds of Northern Terrestrial orchids. Ann Bot Fenn 17: 174-182.

Magrini S, Bronzo F, Onofri S, Scoppola A (2011) Germinazione asimbiotica in vitro di semi immaturi di Orchis palustris Jacq. Studi Trent Sci Nat 89 (in press).

Malmgren S (1992) Large-scale asymbiotic propagation of Cypripedium calceolus-plant physiology from a surgeon's point of view. Botanic Gardens Micropropagation News 1: 59-63.

Malmgren S (1996) Orchid propagation: theory and practice. In: Allen C (ed) North American native terrestrial orchids: propagation and production. North American Native Terrestrial Orchid Conference, Germantown, Maryland, USA, pp 63-71.

McKendrick SL (1996) The effects of fertilizer and root competition on seedlings of Orchis morio and Dactylorhiza fuchsii in chalk and clay soil. New Phytol 134: 335-342.

Mead JW, Bulard C (1975) Effects of vitamins and nitrogen sources on asymbiotic germination and development of Orchis laxiflora and Ophrys sphegodes. New Phytol 74(1): 33-40.

Mead JW, Bulard C (1979) Vitamins and nitrogen requirements of Orchis laxiflora Lam. New Phytol 83: 129-136.
Mitchell RB (1989) Growing hardy orchids from seeds at Kew. The Plantsman 11: 152-169.

Miyoshi K, Mii M (1988) Ultrasonic treatment for enhancing seed germination of terrestrial orchid, Calanthe discolor, in asymbiotic culture. Sci Hortic 35: 127-130.

Miyoshi K, Mii M (1995) Enhancement of seed germination and protocorm formation in Calanthe discolor (Orchidaceae) by $\mathrm{NaOCl}$ and polyphenol absorbent treatments. Plant Tissue Cult Letters 12: 267-272.

Miyoshi K, Mii M (1998) Stimulatory effects of sodium and calcium hypochlorite, pre-chilling and cytokinins on the germination of Cypripedium macranthos seed in vitro. Physiol Plantarum 102: 481-486.

Murashige T, Skoog F (1962) A revised medium for rapid growth and bioassays with tobacco tissue cultures. Physiol Plantarum 15: 473-497.

Pedroso MC, Pais MS (1992) Minituber production from immature seed suspension culture of Orchis papilionacea. In Vitro Cell Dev Biol 28: 183-186.

Raghavan V, Torrey JG (1964) Inorganic nitrogen nutrition of the seedling of the orchid Cattleya. Am J Bot 51: 264-274.

Ranal MA, Santana DG (2006) How and why to measure the germination process? Revista Brasileira de Botânica 29(1): 1-11.

Rasmussen HN (1995) Terrestrial orchids from seed to mycotrophic plant. Cambridge University Press, New York, New York, USA.

Rossi W (2002) Orchidee d'Italia. Quaderni di Conservazione della Natura 15, Ministero dell'Ambiente - Istituto Nazionale Fauna Selvatica, Roma, Italy.

Schnittler M, Köppel C, Rennwald E, Hirneisen N (2001) European National Red Lists of Threatened Vascular Plants. Project report and description of the corresponding data base. Third stage. Council of Europe, Strasbourg, France.

Scrugli A, Cogoni A (1994) Asymbiotic germination's tests in Orchis laxiflora Lam. Caesiana 2: 1-8.

Seaton PT, Hu H, Perner H, Pritchard HW (2010) Ex situ conservation of orchids in a warming world. Bot. Rev. 76: 193-203.

Seaton PT, Pritchard HW (2008) Life in the Freezer. Orchid seed banking for the future. Orchids 77: 762-773.

Sgarbi E, Grimaudo M, Del Prete C (2007) In vitro asymbiotic growth of Mediterranean terrestrial orchids from immature seeds. J Eur Orch 39(3/4): 611-624.

Steele WK (1996) Large-scale seedling production of North American native terrestrial orchids. In: Allen C (ed) North American native terrestrial orchids: propagation and production. North American Native Terrestrial Orchid Conference, Germantown, Maryland, USA, pp 11-26.

Stewart SL, Kane ME (2006) Asymbiotic seed germination and in vitro seedling development of Habenaria macroceratitis (Orchidaceae), a rare Florida terrestrial orchid. Plant Cell Tissue Organ Cult 86: 147-158.

Swartz ND, Dixon KW (2009) Terrestrial orchid conservation in the age of extinction. Ann Bot 104: 543-556.

Vaasa A, Rosenberg V (2004) Preservation of the rare terrestrial orchids in vitro. Acta Universitatis Latviensis, Biology 676: 243-246.

van Waes JM (1987) Effect of activated charcoal on in vitro propagation of western European orchids. Acta Horticulturae 212: 131-138.

van Waes JM, Debergh PC (1986) In vitro germination of some Western European orchids. Physiol Plantarum 67: 253-261.

Vereecken NJ, Dafni A, Cozzolino S (2010) Pollination syndromes in Mediterranean orchids - Implications for speciation, taxonomy and conservation. Bot Rev 76: 220-240. 
Viswambharan S, Cripps R, Ramsay MM, Atherton C, McMichen M, Prendergast G, Rowntree JK (2006) Conservation in vitro of threatened plants - Progress in the past decade. In Vitro Cell Dev Biol 42: 206-214.

Yamazaki J, Miyoshi K (2006) In vitro asymbiotic germination of immature seed and formation of protocorm by Cephalanthera falcata (Orchidaceae). Ann Bot 98: 1197-1206.

Znaniecka J, Lojkowska E (2004) Establishment of in vitro culture collection of endangered European orchids. Bulletin of the Botanical Gardens 13: 69-73. 